\title{
Postscript to "Anthropological Data Regarding the Adaptiveness of Hebephilia”
}

\author{
Raymond Hames $\cdot$ Ray Blanchard
}

Published online: 29 May 2013

(C) Springer Science+Business Media New York 2013

In our Letter to the Editor, entitled “Anthropological Data Regarding the Adaptiveness of Hebephilia" (Hames \& Blanchard, 2012), we neglected to acknowledge Clancy's (2012) prior Scientific American blog post on the issue of the adaptiveness of hebephilia. In that post, she recognized, as did we, the importance of Kramer's (2008) work on the fitness consequences of hebephilia. Dr. Clancy's blog post can be found at: http://blogs.scientificamerican.com/context-and-variation/ 2012/01/18/interrogating-claims-about-natural-sexualbehavior-more-on-deep-thinking-hebephile/. We are writing this postscript to call the interested reader's attention to Dr. Clancy's piece.

\section{References}

Clancy, K. (2012, January 18). Interrogating claims about natural sexual behavior: More on deep thinking hebephile. Available at http:// blogs.scientificamerican.com/context-and-variation/2012/01/18/ interrogating-claims-about-natural-sexual-behavior-more-ondeep-thinkinghebephile/.

Hames, R., \& Blanchard, R. (2012). Anthropological data regarding the adaptiveness of hebephilia [Letter to the Editor]. Archives of Sexual Behavior, 41, 745-747.

Kramer, K. (2008). Early sexual maturity among Pumé foragers of Venezuela: Fitness implications of teen motherhood. American Journal of Physical Anthropology, 136, 338-350.
R. Hames ( $\square)$

Department of Anthropology, University of Nebraska, Lincoln,

Lincoln, NE 68588, USA

e-mail: rhames2@unl.edu

R. Blanchard

Department of Psychiatry, University of Toronto, Toronto, ON,

Canada 